\title{
3 Of Missionaries, Martyrs, and Makahnas
}

\author{
Engendering the Marianas Mission, Part I
}

\begin{abstract}
The first of two chapters on missionary manhood in the Marianas, this chapter focuses on the mission's beginnings and founder, Diego de Sanvitores. The Spanish Jesuit saw himself - and was perceived by others as - another Francis Xavier. Print technology, which circulated images and stories of saintly exemplars worldwide, offered a cultural template for such mimetic copying in the flesh. As Sanvitores fashioned himself into another Xavier, he sought to refashion the Mariana Islands, aided by Spanish colonial authorities. Violence and loss of life came to define this mission. Struggles for male spiritual hegemony between the Jesuits and indigenous shamans escalated hostilities. Sanvitores was killed and hailed as a martyr, drawing more men to the Marianas in search of Catholicism's most heroic male death.
\end{abstract}

Keywords: Diego de Sanvitores, Mariana Islands, martyrdom, Spanish colonialism, print media

Today a flight from Rome to Guam in the Marianas traverses an aerial distance of more than 12,00o kilometers. The inconvenience the modern traveler experiences pales in comparison to the challenges of journeying to the islands in the early modern period. The Jesuits who set up the first European mission in this Pacific archipelago came on land and sea routes via Spain and the Americas by routes almost 24,00o kilometers long, or over half the earth's circumference. If we take the European perspective for the moment and posit Rome as the center of Catholic Christianity, Guam was its most remote point on the other side of the world, the gateway into the blue vastness of Oceania and a crucial way station on Catholicism's path to becoming a global religion. ${ }^{1}$

1 This default perspective on the Catholic Church is usefully reversed in Ditchfield, 'Decentering the Catholic Reformation.'

Strasser, U., Missionary Men in the Early Modern World: German Jesuits and Pacific Journeys. Amsterdam: Amsterdam University Press, 2020 DOI: $10.5117 / 9789462986305 \_$CHO3 
The journey sparked dramatic transformations among the peoples whom the Jesuits encountered. The Spanish Jesuit Diego de Sanvitores (1627-1672) launched the island mission in 1668 and recorded initial successes. Merely a few months into the mission, however, some Chamorros violently opposed the European intruders, inaugurating decades of resistance to the outsiders. Brutal warfare, forced reduction, and epidemic disease eventually secured Spanish victory and Christianization but they also created a situation that brought the island population to the brink of demographic extinction. These mass indigenous deaths would not be publicly commemorated until much later. The deaths of the Jesuits, on the other hand, were publicized in the Spanish Empire and in Europe, drawing more men who had a desire to become martyrs to the Marianas. The violence in the Marianas thus tied two parts of the globe together, affecting each in radically different ways.

For the missionaries who went to work in the Marianas, it was also an inward journey transforming them across the span of years and often decades spent in this Pacific locale into a person who both resembled but also differed from the one who first stepped ashore. Having come of age in the homosocial environment of European Jesuit colleges, the missionaries first came into growing contact with the larger world and proved their manhood aboard transoceanic ships. Missionary manhood came into its sharpest contours, though, in the mission field. Only there and then, European ideas about evangelization and self were gradually reshaped in the close encounter with another people, including indigenous women, into workable practices of relating to 'the other' and into flexible self-understandings that were continuous with the European Jesuit project yet allowed for accommodation. It was one thing to want to follow Francis Xavier's example in the abstract, but another altogether to put this example into practice in a Pacific archipelago that even the much-traveled Xavier had never reached and whose population was barely known to Europeans.

This chapter and the following will look at this in some detail by considering the life histories of a Spanish and a German Jesuit, Diego de Sanvitores and Augustinus Strobach. They each took Xavier as their inspiration and their life histories intertwine through mimesis of Xavier, leading both of them to the same Pacific archipelago. The two stories illustrate that Xavier's example, many decades after his death and canonization, continued to exert a powerful pull on the imagination and actions of Jesuits. Xavier's writings, stories told about him, and his iconographic legacy furnished late-seventeenth-century Jesuits like Sanvitores and Strobach with scripts of missionary manhood that could be enacted by aspiring saints and recognized by others as marks of holiness. Like all scripts, however, those 
about Xavier were open to elaboration and needed to be accommodated to specific missionary situations. Although Sanvitores and Strobach both strove to follow in Xavier's footsteps, they never met but rather labored in the Marianas a decade apart, a long time in a mission as dramatic as this one. Their biographies bring different facets of Jesuit manhood in the Marianas mission into view, warranting treatment in two consecutive chapters, but they each point to the inseparability of missionary self-fashioning and the reform of others.

This chapter traces the beginnings of the Marianas mission and the violent clashes between islanders and intruders by linking it to the evolution of its Jesuit founder, Diego de Sanvitores, an Iberian follower of Francis Xavier. Sanvitores, in the course of turning himself into a 'new Xavier' in the Marianas and encountering violent opposition to his efforts, came to see in martyrdom the only way to advance the faith further. He hoped for and then suffered Tridentine Catholicism's most heroic male death, a fate for which the original Xavier had longed in vain. While Sanvitores deliberately fashioned himself into a new Francis Xavier, the Spaniard also set about refashioning the Marianas mission field that was to serve as the external mirror of his interior transformation. Asserting his missionary masculinity, Sanvitores reimagined the Pacific archipelago as a feminized space ruled by the Virgin Mary and her Jesuit acolytes, whose task it was to guide their island charges toward Christian salvation. He enlisted the support of Spanish colonial authorities to make the complex spiritual and political reorganization of island society possible. Everywhere in the Jesuit missions, the introduction of Christian norms of marriage, sexuality, and gender was a central component of evangelization. In the Marianas, however, local worlds were overturned in particularly dramatic ways due to a fundamental clash between European and island norms, including matrilineal traditions, and on account of the violence and extraordinary loss of life that came to define the missionary encounter in the Pacific archipelago.

When European Catholicism met Chamorro culture in 1668, the encounter did not immediately take place on a military frontier but initially along what Kathleen Brown termed a 'gender frontier' where two culturally specific systems for understanding gender and sexuality, as well as the cosmos, collided. ${ }^{2}$ This chapter centrally concerns itself with struggles for male spiritual hegemony between the Jesuits and indigenous shamans that overshadowed the early days of the mission from its beginning through the first Great War and Sanvitores's death in April 1672. Indigenous beliefs in anitis ('ancestral 
spirits') and deeply held respect for makahnas ('shaman-sorcerers') influenced the islanders' responses in the Marianas mission. These indigenous frameworks had a very important yet paradoxical effect on the course of events. On the one hand, beliefs in an ancestral afterlife and in makahnas as ritual experts made the islanders more receptive to Catholicism, enabling the Jesuits to gain a foothold in the complex island world. On the other hand, the same beliefs led to the sharpest clashes between islanders and Europeans, and set in motion a highly destructive spiral of symbolic and physical combat. Missionaries and makahnas represented hegemonic masculinities among their people, at once uncannily alike yet diametrically opposed. They each claimed a monopoly on the spirit world, which in their view placed them above political authorities and which they were ready to defend, if necessary, by relying on the worldly weapons of war. The spiritual combat behind the military goes a long way toward explaining the decade-long destructive violence that swept the islands in the late seventeenth century and left so many dead in its wake. Moreover, the Jesuits' homosocial traditions and rejection of marriage meant that, from the indigenous point of view, these missionary men could not be inserted in the all important clan system. The Jesuits' inability to assimilate into island society made all their alliances unstable and contributed to the quick escalation of hostilities. ${ }^{3}$

\section{'A Copy with a Soul': The Beginnings of the Marianas Mission}

Although Jesuits can be found among the earliest critics of European colonialism, in the end colonial power enabled their apostolic labors overseas and Jesuit missions in turn underwrote European political dominance. The history of the Marianas provided an intriguing exception to the general rule that Catholicism followed on the heels of European colonial conquest. Here the Jesuits led the way, not the Spanish crown. Ferdinand Magellan (c. 1480-1521) first chanced upon the archipelago during his 1521 quest to seize the riches of the Spice Islands for Spain. ${ }^{4}$ After the Chamorros seized

3 Chapter 1 highlighted the frictions between the Society's homosocial structure and European institutional and familial norms, particularly in Protestant areas. I would like to thank David Atienza for directing my attention to the even more far-reaching ramifications of homosocial traditions and clerical celibacy for missionary work among the clans of the Marianas.

4 Foundational works on the Marianas missions: Hezel, 'From Conversion to Conquest'; Hezel, From Conquest to Colonization; Diaz, Repositioning the Missionary; Rogers, Destiny's Landfall, esp. pp. 41-73; Russell, Tiempon I Manmofo'na, esp. pp. 291-322 Coello de la Rosa, Jesuits at the Margins. 
a European rowboat, in keeping with their logic of gift exchanges among strangers, Magellan, who followed different rules of engagement, retaliated and dubbed the archipelago Islas de los Ladrones ('Islands of Thieves'). Twenty-four years later, Miguel López de Legazpi (c. 1502-1572) formally claimed the Ladrones for Spain en route to the Philippines, where he then founded Manila. Soon thereafter, the southern tip of the Ladrones became a vital point of orientation and stopover for the Manila Galleon trade that fused the economies of Asia, the Americas, and Europe into a global circuit for the first time in history.

The archipelago's strategic importance notwithstanding, Spain stayed clear of setting up a colonial government in the Ladrones because the costs of formal possession outweighed the potential benefits. Spanish authorities deemed the islands too poor in mineral resources to warrant colonization. ${ }^{5}$ Silver was the lifeblood of the Spanish Empire, with arteries running through its American parts, Mexico and Peru, and its Asian parts centered on Manila. Once the galleon trade commenced, it flowed across the Great Ocean in between. In the Spanish East Indies, colonial authorities sought to maximize the profit from the lucrative Manila-Acapulco trade. They tried to keep the expenses of defending the Pacific imperial frontier low and avoid the costly conquest and colonization of new territories. ${ }^{6}$ A chain of fifteen islands that stretched across some 500 miles of turbulent ocean waters, lacked mineral resources, and had limited agricultural prospects held virtually no appeal.

The same lack of material wealth, however, caught the attention of Diego de Sanvitores on his first journey from New Spain across the Pacific. In April 1662, he sighted the inhabitants of the Ladrones during the customary stopover of the Manila Galleon and was moved to tears by their poverty and that of their islands. 'Why,' he bemoaned, 'are there so few men who are greedy for the richest mines in the world, namely the souls redeemed by the Precious Blood of Christ?'7 Like his later followers, Sanvitores pitted a material against a spiritual economy that had Christ's blood sacrifice as its major currency, and identified the islands as an especially fertile mission field. The very absence of gold underscored the purity of the Jesuit mission. The encounter left Sanvitores with a sense of a vocation to launch a mission from the Philippines, where he first began his work as a missionary in the Pacific.

Although Jesuits referred to Manila as 'the warehouse of the faith,' Sanvitores learned that colonial authorities in the city calculated in 
hard currency rather than souls. ${ }^{8}$ After years of fruitless lobbying for a mission to the Ladrones, he resolved that a better approach consisted of dealing with the court in Madrid, the city of his birth, where he could rely on family networks alongside those of the Society of Jesus. Sanvitores recruited his father in Madrid to deliver a memorandum to King Philip IV (r. 1621-1665). The text contained stern reminders of a Christian monarch's duties and warned King Philip of impending death. Sanvitores wrote the text in the authoritative voice of none other than Francis Xavier. ${ }^{9}$ Perhaps Sanvitores took a cue from the playbook of the Philippine Jesuit Francisco Colin (1592-1660). Colin's account of 'evangelical labor in the islands of the Philippines' was first presented to the king in 1658 and then published in Madrid in 1663 as Labor evangelica, ministerios apostolicos de los obreros de la Compañia de Iesvs, fvndacion, y progressos de sv provincia en las islas Filipinas. It placed missionary activity in this part of world under the aegis of Francis Xavier (fig. 9). The frontispiece is dominated by an oversized Xavier, who stands at the center of an archipelago in the Pacific, his hands extended across and toward smaller islands with church buildings, while ships approach the towering figure from front and back. Xavier's visual hyper-presence in a book that narrated the life histories of those who lived a century later apparently perturbed the inquisitorial examiner of the publication, who noted the mismatch in his authorization. ${ }^{10}$

Sanvitores, to be sure, did not perceive such a disjuncture between Xavier's time and his own, or, for that matter, between the saint's identity and his own. The daring ventriloquism of the memorandum was no isolated incident. Rather, the sources suggest that Sanvitores in word and deed rather self-consciously scripted himself as another Xavier, and that those around him came to believe that he indeed was a late-seventeenth-century version of the apostle of the Indies - a Spanish avatar of the saint, as it were. Sanvitores's first printed biography tells the story of the embodied resemblances between Sanvitores and Xavier; we might think of it as an imaginary expression of Jesuit homosociality detached from specific locals and time periods. Written by Francisco García (1641-1685) and published in Madrid in 1683, Viday martyrio de el Venerable Padre Diego Luis de Sanvitores was composed with an eye toward canonization, and hence García's portrayal of Sanvitores as another Xavier served the transparent rhetorical purpose of presenting 


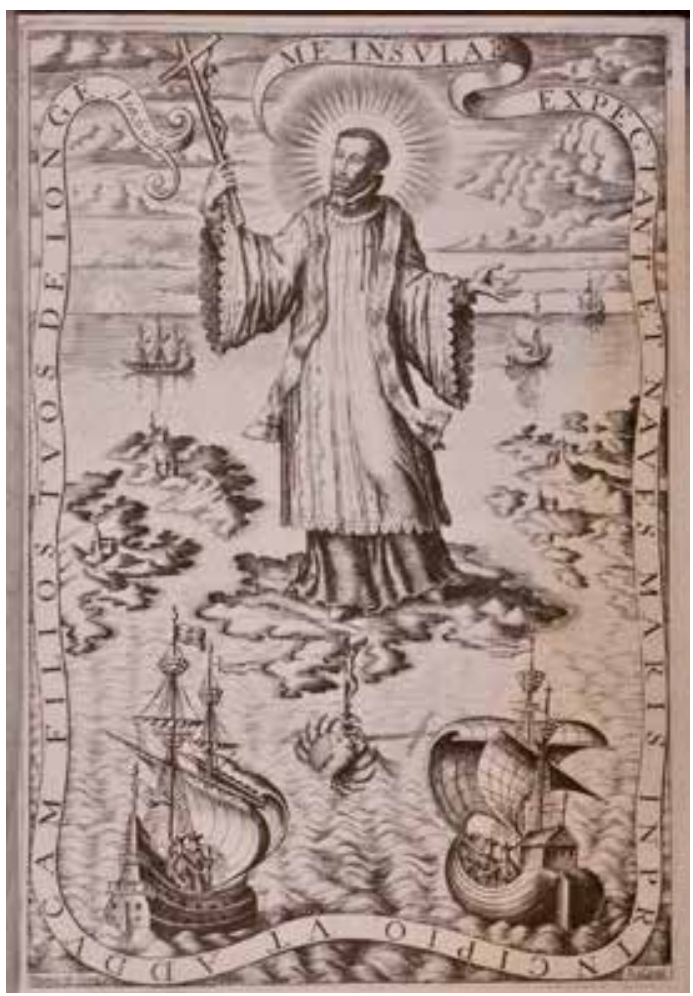

Figure 9 Frontispiece, Francisco Colin, Labor evangelica, ministerios apostolicos de los obreros de la Compañia de lesvs, fvndacion, y progressos de sv provincia en las islas Filipinas (Madrid: Joseph Fernandez de Buendia, 1663). Source: Rose Marie San Juan, Vertiginous Mirrors: The Animation of the Visual Image and Early Modern Travel (Manchester: Manchester University Press, 2011), p. 12.

him as a bona fide saint. ${ }^{11}$ Still, García worked from other materials that pointed to Sanvitores's deliberate enactment of a Xaverian narrative and his companions' ready attribution of a Xaverian identity to him.

Sanvitores's embrace of Xavier was inseparable from his embrace of the missionary life, and it developed over time. First came an early identification with Ignatius and prolonged struggles with his mother and father over his desire to become a Jesuit. As much as Sanvitores's mother, Doña Maria Alonso Maluenda, later tried to dissuade him from joining the Society of Jesus, her actions at the time of Sanvitores's birth had marked him as a son of Ignatius. During the most painful moments of labor, when she feared they would both die, the story goes, Sanvitores's mother pressed upon her aching body a signature of Saint Ignatius's to find relief and then 
deliver him easily. ${ }^{12}$ The child's early articulation of desire for the Jesuit life met strong resistance from both his parents. Initially united in their opposition, the parents disagreed on the right course of action for dissuading their determined son, and Diego's mother eventually surrendered to his unbendable will after she had a vision in which Ignatius appeared leading him, a bloody martyr crown on his head, and telling her to desist from claiming him for herself: 'Do not try to take your son with you, because I want him in my house as a saint.'13 Diego moved into the house of the Jesuits. He became a minister of the college in Oropesa when, "[e]veryone felt that he was a most observant and religious man, so much so that he seemed a "living rule" of Saint Ignatius." ${ }^{14}$

If his mother first branded Sanvitores a son of Ignatius at the time of his birth by applying the founder's signature to her body, Sanvitores as an adult Jesuit rebranded himself into a version of Xavier. As Sanvitores recounted in his application for the overseas missions, in November 1657 he suffered a serious illness and wished to die. But then 'turning my whole being to the missions, I asked that they bring me a signature of Saint Francis Xavier, and another that I had of the Venerable Martyr Marcello Mastrilli.' ${ }^{15}$ The latter had been called 'the second Xavier'; he had seen Xavier at his sickbed in 1634 after a portrait of the saint was moved next to him. Mastrilli became a missionary to Japan, where he died as a martyr in $1637 \cdot{ }^{16}$ Similarly, Sanvitores made a vow to 'spend all my life and strength in the ministry of the missions, principally among unbelievers.' Swift recovery followed thanks to the 'intercession of Saint Xavier' so that 'on the very feast day of Saint Francis Xavier the doctors gave order that I get up.'17

From that moment on, Sanvitores sought to walk in Xavier's footsteps and extend the saint's missionary work in space and time. In his letter of application, Sanvitores professed to feel 'deeply attracted by the Japanese [...] because of Francis Xavier. ${ }^{18}$ His invocation of Mastrilli suggests martyrdom was already much on Sanvitores's mind. In fact, in recounting his mother's vision of Ignatius in which the founder allegedly claimed her son for the Jesuits in the first place, Sanvitores made a telling change to the punch line.

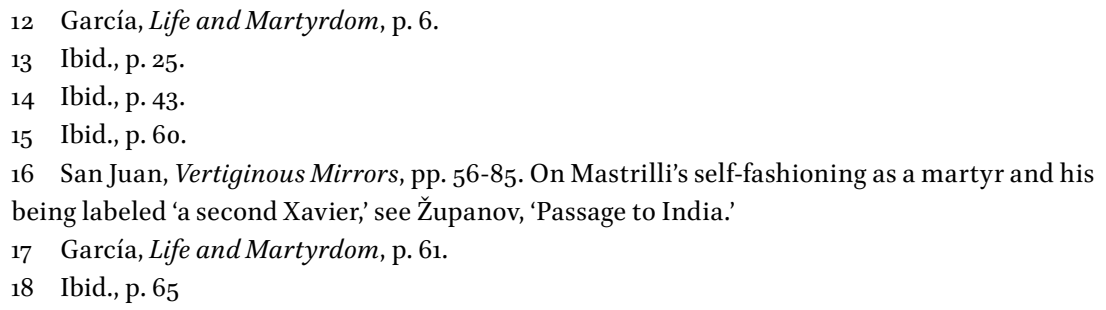


His version supplants 'I want him in my house as a saint' with 'Let him be, for he is to be a martyr. ${ }^{19}$

Martyrdom had a particular role to play in generating not only new Christians but also new missionaries, which was vital to the long-term success of the Jesuit order. The earliest Christians had understood the blood of martyrs as the seed that spawned new Christians, and the Society of Jesus had revitalized the idea in print and practice during the early modern phase of global Christianization. ${ }^{20}$ Martyrdom promised both a rich harvest of new Christians and new missionaries. As the most heroic form of death, it engendered moral exemplars whose redemptive suffering in faraway lands drew other men into the missions, thus extending the reach of the order's corporate body in space and time. Given its dual effects, martyrdom may have been the most potent means of successful clerical reproduction. A strong desire for martyrdom pulsed through the Society of Jesus.

But the problem with martyrdom was that the dying had to be just right. Here the demise of Antonio Criminali (1520-1549), Francis Xavier's successor on the Fishery Coast of India, at the hand of a Badaga soldier offered a cautionary tale of missionary waste. After it transpired that Criminali willingly ran into the arms of the enemy, the Jesuit hierarchy downgraded his death from an alleged martyrdom to a regretful and reckless quasi-suicidal act, and reiterated the importance of seeking the 'white martyrdoms' of more quotidian suffering to the success of a mission. ${ }^{21}$ For the Society of Jesus, which did not operate within a stable parish framework, but embraced a male missionary model of always being on the move, the premature, useless deaths of its members threatened to turn a new mission into a mere flash in the pan. Proper institutional reproduction required an effusive type of missionary who was unrestrained, even restless, and ever ready to spill generative blood. Yet it equally strongly demanded that members direct these effusive impulses toward long-term objectives. Affective self-governance, already required for and trained during the sea voyages, mattered greatly under hostile circumstances in mission fields.

These conflicting demands and their dangers were not lost on Sanvitores. Nor was the need to put his superiors' worries about reckless actions to rest if he wished his application for the overseas mission to go forward. In making a final pitch to be sent out for the salvation of the 'most abandoned

19 Ibid., p. 59 .

20 Burschel, Sterben und Unsterblichkeit, esp. pp. 229-288.

21 On Criminali and the order's latent ambivalence about martyrdom, see Županov, 'The Art of Dying in the Tropics.' 
souls,' Sanvitores addressed the issue head-on: 'I must make clear that my feelings in this matter are not of such sort that I desire the missions for the sake of martyrdom, but only for the sake of the missions I would fear no labor or manner of death for one soul that I might win for Christ or for one only additional degree of love for God or my neighbor.'22 In his quest to strike the right balance, Sanvitores embraced Xavier as a model. He tried to imitate Xavier in all aspects of his being and persuade others that he was an avatar of the saint. A striking passage from García's vita notes the agreed-upon likeness and offers a series of explanations for it:

To gauge the greatness of the sanctity of this servant of God it is enough to know is that he is a second Xavier. This is the name that all who interacted and communicated with him gave him, and no attribution is repeated more often in the reports and letters. And nothing was said more often in all of our histories then that no one seemed to resemble Saint Francis Xavier more than this admirable man; and it seems that God has consoled those which did not merit to see the great Apostle of the Indies, by giving us a copy of his spirit, just as he consoled the world, which did not know Paul by giving it Xavier; and even if a copy always loses something compared to the original and also the copy that one makes of the same image, and hence I do not pretend that the Venerable Padre San Vitores is the same as Saint Francis Xavier, just like Saint Francis Xavier is not the same as Saint Paul, nor could anyone deny that the second Apostle of the people resembled the first in his virtues, and gifts, it seems that the third resembled the second in the same perfections and prerogatives. ${ }^{23}$

García here carefully eschews a direct equation between his protégé Sanvitores and the canonized Xavier ('I do not pretend'), yet he simultaneously puts the embodied resemblance between the two Jesuits beyond question ('nor could anyone deny'). In fact, the passage opens with the assertion that the historical record ('nothing was said more often') fully warrants characterizing Sanvitores as 'a second Xavier.' Later in the book, García uses the memorable characterization of Sanvitores as 'a copy with a soul.' Images of animated copies and visual reproduction also abound in this passage. They bespeak the early modern cultural fascination with the power of images not merely to represent but to make present the sacred, 
with extraordinary transformations or even transmutations, as well as the notion that the human body could manifest holiness physically. ${ }^{24}$ García casts God as the originator of a generative process that instantiates as an apostolic lineage running from Saint Paul to Saint Francis Xavier to the saintly Sanvitores. It is an entirely patrilineal mode of generation, which bypasses women and sexual reproduction, and is accomplished instead through the infusion of spirit - a form of pneumatic life-giving that in Aristotelian medical theory was seen as a quality of semen. ${ }^{25}$ 'A copy with a soul' was an animated life form.

Notably, Xavier is at once a special person and a mere link in this patrilineal chain. He alone is the new Paul, resuscitating the spirit of the apostle and ushering in a new age of global evangelization that has the Society of Jesus as its vanguard. At the same time, Xavier serves as a simple relay between early Christianity and global Christianity in making the Pauline model available to other Jesuits like Sanvitores, who then infuse it with new life. In García's scheme of things, Xavier's position is structurally similar to what Arnold Davidson has described for the place of Saint Francis in paving the way for the somatic expression of mystical experiences through his unique, miraculous stigmatization. Francis had to physically morph into Christ for those that came after him to morph into a form of Francis, and in his uniqueness he set an ultimately unachievable benchmark for later mystics. ${ }^{26}$ Similarly, García's Xavier becomes the measure for all who aspire to the Pauline model, but who will inevitably fall short of Xavier's reanimation of Paul. García measures this distance by talking about the difference between a copy and an original. As a copy of the original, Xavier is essentially like but already no longer the same as Paul. As a copy of the copy, Sanvitores is like but not the same as Xavier and even less like Paul.

García's analogy was no mere metaphor. Long after the rise of representational art, early modern culture continued to ascribe to religious images a capacity that went far beyond pure mimicry. Seen as conduits of the sacred, images were thought capable of transmitting the transcendent to the beholder and thereby enabling spiritual transformation in the flesh, or an animated, embodied mimesis of the holy in those who knew how to tap

24 Newman, Promethean Ambitions. Alchemists were frequently criticized as usurpers of power that belongs to God the creator alone.

25 According to Aristotle, biological reproduction still required a man and a woman, but early modern interpreters of Aristotle used his claims about the miraculous powers of sperm to theorize about the possibilities of artificial life. See Newman, Promethean Ambitions, pp. 170-171. 26 Davidson, 'Miracles of Bodily Transformation.' 
into the potency of images. ${ }^{27}$ The same was said of saints themselves. In his Flos sanctorum, one of the most influential hagiographic texts of the period, Alonso de Villega (1534-1615) declared that the church's saints operated like 'living portraits,' giving life to what would otherwise remain bloodless biblical truths. Published in 1583 , the text breathes Tridentine doctrine, including the Council of Trent's proclamation that religious education demanded visual representation of the church's saints. ${ }^{28}$

If saints were living portraits' and visual media of the holy, artistic portraits of saints served to extend the saints' presence across time and space, linking together expanding networks of devotees and believers. Precisely because they were animated, images could fill the gap that arose when direct physical contact was impossible. This is why the image of Xavier placed next to the sick Mastrilli during the plague of 1634 could serve as a portal for the saint's appearance. Portraits also brought Sanvitores and Xavier closer together. When Sanvitores arrived in Mexico City on his journey to the Ladrones - an arrival his followers likened to that of Saint Francis in Goa - he began by seeking to revitalize the local sodality of the 'Apostle of Asia.' Before Sanvitores departed, the congregation begged him to sit for a portrait. They hung his painted image in view of their painting of Francis Xavier, the 'Apostle of Asia' eyeing the Pacific-bound aspiring holy man, and the congregation gazing at the sacred images to transpose models of holiness into their lives in New Spain. On a later return trip to Mexico City, Sanvitores again posed for a painting, and the congregation hired a renowned painter to produce a better likeness. ${ }^{29}$ The greater the verisimilitude, this suggests, the more efficacious the image.

Sanvitores's willingness to sit for portrait twice for his devotees points to the element of self-stylization in his becoming a 'second Xavier.' Xavier himself sat for two portraits during his lifetime - one for Goa, one for Rome - to serve as prototypes of this kind. ${ }^{30}$ Sanvitores's biographer García reports other, quotidian enactments of Xaverian scripts:

[Sanvitores] so much dedicated himself altogether to the salvation of souls, as I said, tried to be Xavier in his actions and his sayings; and he constantly petitioned the saintly apostle, and solicited him with constant prayers; therefore, he read every day, without skipping a single one, a

27 San Juan, Vertiginous Mirrors, contains many examples. On the reevaluation of Hans Belting's notion of a shift from 'imago' to 'art' within visual studies at large, see ibid., p. 5 .

28 Leone, Saints and Signs, pp. 3-4, p. 7 .

29 Cited from the original. Translation mine. García, Vida y martyrio, p. 185.

30 Leone, Saints and Signs, p. 403. 
chapter from his vita, or a part of his epistles, or instructions; and this man attained this so perfectly, that one of his companions affirmed that there was not a bit of difference in his actions from those of the holy apostle, he let himself be guided by what he found in his apostolic life; and to read the vita of Saint Francis Xavier, it seems, is to read the life of the Father Sanvitores. ${ }^{31}$

Sanvitores, this suggests, strove to channel Xavier by mimicking his every deed and speech acts. Devotion and mimesis went hand in hand: Sanvitores prayed to, petitioned, and solicited the saint; every day ('without skipping') he read writings about and by Xavier to imitate the saint perfectly and thereby transform himself from the admirer into the protagonist of a Xaverian apostolic life. This was an effort at embodied resuscitation, a quest for corporeal conformity, as Sanvitores behaved and spoke just like Xavier down to the detail: 'there was not a bit of difference.'

It stands to reason that the body would take on added importance as a means of expressing identity for members of a religious order that eschewed a standardized dress code at the very moment in time when European culture at large experienced the invention of fashion..$^{32}$ The Society's dress regulations only stipulated that attire be appropriate to the vow of poverty and local sartorial norms. ${ }^{33}$ Anti-Jesuitical literature's trope of the order's shifting, deceptive guises suggests this was no trivial matter. Sanvitores freely availed himself of the possibilities: upon landing in the Ladrones, he cast off his robes to don a new island garb of palm leaves. The less stable the sartorial regime, one could argue, the more regulated bodily comportment needed to be if one wished to be recognized as 'a living portrait' or saint. Or inversely, the more fully one embodied and enacted the holy, the less one needed to worry about outer layers of identity. Francis Xavier wore low-key clothing. Sanvitores fashioned a palm garment that the local Chamorros apparently found quite peculiar and laughable. ${ }^{34}$ Yet believers still recognized him as a Xavier; the right body made the credible saint.

Of course, comparatively few people encountered aspiring saints in the flesh, and hence the texts that transported their stories to those who lived

31 García, Vida y martyrio, p. 308.

32 Rublack, Dressing Up.

33 On the relationship between minimal regulation and intelligibility of the Jesuit as a type, see Levy, 'Jesuit Identity.'

34 Diaz, Repositioning the Missionary, pp. 165-166. 
elsewhere or thereafter bore much of the burden of establishing proof of their sainthood. Thanks to early modern print technology, stories of the holy could be reproduced more easily and travel much greater distances than in the Middle Ages. The availability of mimetic reproduction and multiplication via print helps us understand more fully why García's description talked about original and copies in his lengthy rumination on the resemblance between Sanvitores and Xavier, and why he chose the punch line: 'To read the vita of San Francis Xavier, it seems, is to read the life of the Father Sanvitores.' Reading, writing, copying, and printing: these were mimetic operations and technologies for producing new saints for the Society in a global age. Ignatius, himself transformed by the reading of saints' lives and aware of the importance of Xavier's model, pushed hard for Xavier's writings to become available in print so others could read and copy the first overseas missionary. Sanvitores took this to heart and read to transform himself into another Xavier. For García to write Sanvitores's vita so that readers could recognize the second Xavier and be inspired by him was to close the circle. The technical reproduction of the vita in print served to underpin the reproduction of saintly men. The fifth book of García's biography was dedicated to the Jesuits who followed in Sanvitores's footstep after his violent death and 'in whom he left his spirit, multiplied without doubt.'35 A susceptible reader could imagine his own story added to a future print edition.

Even if his Xaverian spirit lived on, the story of Sanvitores's physical body ended with his killing on the Marianas. In keeping with the implicit promise of his application letter, Sanvitores desired martyrdom, but did not rush into it once overseas. In a letter of 1663 , he still assured his superior general: 'Swords and martyrdom are not soon found here [i.e., the Marianas], nor should we expose ourselves to them until the Lord should place us under them, and we should pray that these happen after we have brought him many souls in heaven. ${ }^{36}$ At first, Sanvitores focused on converting islanders by tossing out so-called ejaculaciones (holy teachings). These perfectly honed phrases were meant to strike at the heart of the Chamorro and 'plant the seed of the Gospel. ${ }^{37}$ Only after things turned sour between Jesuits and islanders did Sanvitores resolve that further evangelization demanded the spilling of his own blood. ${ }^{8}$ Across the Pacific in Mexico City, an ominous 
sign of what was to come reportedly appeared on a painting of Francis Xavier: sweat broke out on his face. ${ }^{39}$

\section{Making Catholics of Chamorros, Making Makahnas of Missionaries}

On June 15, 1668, Diego de Sanvitores finally landed in Guam, a small band of missionaries in tow, as well as lay helpers, including a family and two boy sopranos. Only later did he request the support of professional soldiers and the erection of a Spanish garrison. ${ }^{40}$ Although Sanvitores believed that Francis Xavier had made it possible for him to launch this island mission, from a material point of view, the Jesuit had to credit queen and future regent Mariana and the gendered tactics he used to win her support.

Sanvitores pitched his mission to both King Philip IV (r. 1621-1665) and Queen Mariana of Austria (1634-1696; m. 1649-1665), yet in distinctly gendered ways. As regards the queen, Sanvitores worked in the time-honored Jesuit tradition of providing powerful women with spiritual guidance in exchange for financial and political support. ${ }^{41} \mathrm{He}$ also employed a tactic other Jesuits had used successfully with female patrons by evoking the plight of the poor pagan infants in the Ladrones. ${ }^{42}$ Sanvitores enlisted the help of the queen's Jesuit confessor, Johann Nidhart, whose deep influence on Mariana was controversial at court. ${ }^{43}$ Sanvitores's appeal to the queen's maternal feelings contrasted starkly with his approach to King Philip.

After the death of Philip IV, when Mariana was able to act as the regent of the Spanish Empire, she authorized the foundation of a Jesuit mission in the archipelago and lent the requisite financial, logistical, and military support. ${ }^{44}$ Shortly after his arrival, Sanvitores expressed his gratitude for the queen's patronage by baptizing a first infant girl 'Mariana' and christening the entire archipelago 'Marianas. 45 An ardent devotee of the Virgin Mary, Sanvitores

40 A recurring error in the historiography has Sanvitores arrive with troops. For a correction, see Atienza, 'CHamoru “Adaptive Resistance,"' pp. 7-12. Hezel, When Cultures Clash, p. 17.

41 Hufton, 'Altruism and Reciprocity.'

42 Hsia, Noble Patronage. García, Life and Martyrdom, pp. 142-143.

43 Diaz (Repositioning the Missionary, p. 171) also comments on Sanvitores's gendered approach. On Nidhart, see also Coello de la Rosa, Jesuits at the Margins, pp. 26-27.

44 Rogers, Destiny's Landfall, p. 46.

45 Ibid., pp. 46-47. 
embraced the double entendre of honoring both the Spanish queen and the Queen of Heaven with this new moniker, declaring the crescent shape of the islands a 'fitting pedestal for Mary. ${ }^{46}$ Thus, the Islands of Thieves became the Marianas in the European imagination, a feminization of space in keeping with the Jesuit valorization of the feminine in the abstract, as opposed to women in the flesh. It implied a very different, seemingly softer relationship between Europeans and islanders than the earlier designation of Ladrones (fig. 10). ${ }^{47}$ Yet the presumption of Euro-Christian superiority remained, and it would inaugurate the violent conflicts that soon followed, as well as suppression of the islands' matrilineal traditions. Arguably, the more potent effect of feminizing the island space was its effect on the missionaries themselves as the feminization of the islands helped invite a masculine project of planting the seed of Christ by becoming a martyr. The submission of the feminine, and the obligations and pleasures the came with it, was written into the European patriarchal imagination of missionaries and conquistadors alike.

Meanwhile, the Chamorros had long inhabited a complex island world of their own making and imagination. The crescent of fifteen islands stretching across some 800 kilometers was home to between 24,000 and 30,000 people at the time. ${ }^{48}$ They referred to their archipelago as 'tano's tasi' ('land of the sea'). ${ }^{49}$ The indigenous designation spoke of the ancient times when their islands first emerged from the ocean as well as of the lasting inseparability of water and land, and the need for people to cultivate a symbiotic relationship with both elements for survival. Land for agriculture was scarce and its utility for food production overshadowed by a capricious climate that at its most vicious brought devastating typhoons to the islands..$^{50}$ Expert swimmers from an early age and masterful navigators of canoes, the Chamorros enriched their diet by fishing in the ocean, from the offshore reefs that surrounded the islands to the high seas that lay beyond them. ${ }^{5^{1}}$ Intra-island trade took place not only across the entire archipelago but with islanders from other archipelagos in Oceania. ${ }^{2}$

$5^{2}$ The islanders participated in an elaborate regional exchange system based in what are now known as the Western Carolines. The connection between the archipelagoes was severed once the Carolinians learned of the Spanish conquest of the Marianas and the brutal treatment of the Chamorro population. D'Arcy, People of the Sea. 


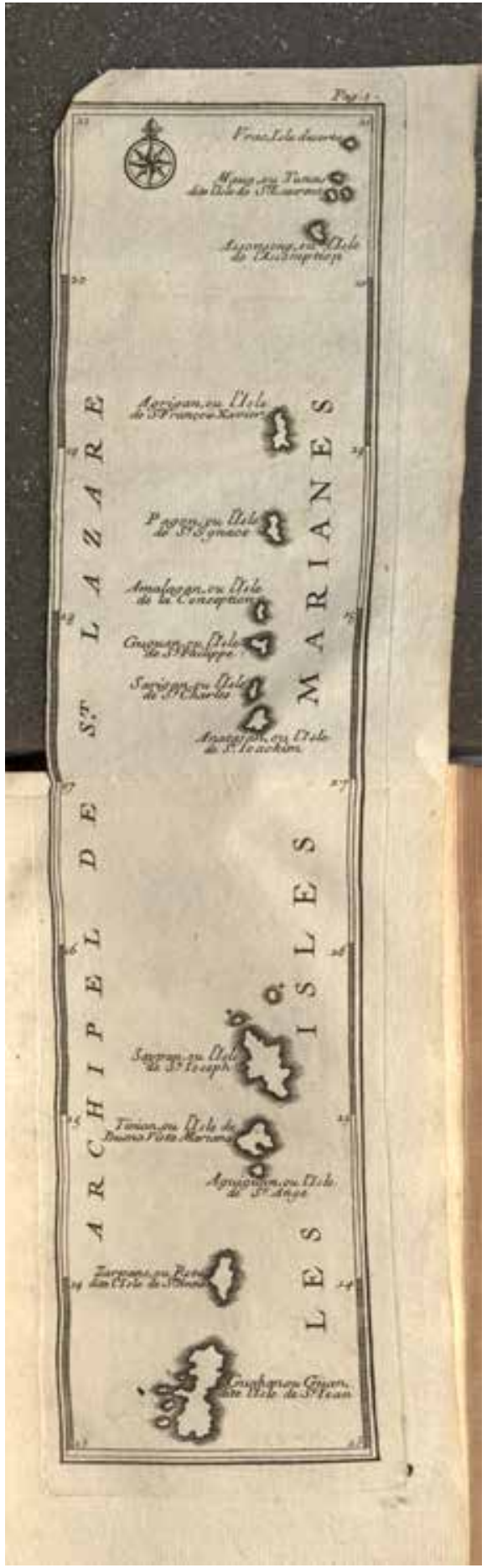

Figure 10 Map of the Marianas. Source: Charles Le Gobien, Histoire des isles Marianes, nouvellement converties à la religion Chrestienne; \& de la mort glorieuse des premiers missionnaires qui y ont prêché la foy (Paris: Nicolas Pepie, 1700). Courtesy of Special Collections \& Archives, UC San Diego Library. 
Family-based clans regulated access to the precious resources of land and water, managing property rights that reached from the islands' soil across their shores out into the sea itself. ${ }^{53}$ In island mythology, a woman was credited with creating the world out of the body of her brother and bringing forth a new people, the islanders. ${ }^{54}$ Kinship and resource distribution in the archipelago followed matrilineal norms. Newlywed couples resided on the land of the groom's maternal uncle. 55 While matrilineality mattered in every family everywhere, not all families and clans were equal and society had three castes. On one end of the spectrum, the highest-ranking nobles, or the original Chamorri, held sway over the more lush coastlines and controlled much of fishing and navigation. ${ }^{56}$ On the other end, lower-ranking commoners inhabited and toiled on the land of others, some at a considerable distance from the coast. ${ }^{57}$ There was no central political authority that unified or ruled over this stratified, clan-based society. Rather, island society was riven by powerful factions, as the most high-ranking clan chiefs controlled among large areas of the major islands, frequently vying for an increase in power and forming shifting alliances with one another. ${ }^{58}$

The internal tensions created an opening for the Jesuit enterprise. If Sanvitores and companions had any chance of evangelizing the far-flung and populous archipelago, it lay in garnering the support of influential islanders. Unless some chiefs embraced Catholicism of their own volition, the mission could not advance. The Jesuits' initial reception was as good as they could have hoped. Chief Kepuha of Agaña on Guam approached the Jesuits after they arrived at Guam and invited them to settle in his community (fig. 11). He provided them with space to build a church, aptly named Dulce Nombre de Maria, or Sweet Name of Mary, by Sanvitores, and a college, and he accepted baptism. ${ }^{59}$ Thus, Agaña became the mission headquarters while Kepuha became Don Juan Kepuha, the mission's first trophy convert. Soon other members of the Chamorri followed suit and asked the Jesuits for baptism. ${ }^{60}$

53 Rogers, Destiny's Landfall, pp. 35-36.

54 This myth is described more fully in Atienza and Coello de la Rosa, 'Embodied Silent Narratives,' p. 247. See the following chapter for a longer discussion.

55 On avuncular clan structure and residence patterns, see Cunningham, Ancient Chamorro Society, pp. 170-175.

56 Rogers, Destiny's Landfall, p. 23.

57 Alkire, An Introduction, p. 22.

$5^{8}$ Atienza, 'Priests, Mayors and Indigenous Offices,' esp. pp. 33-34.

59 Viana, Far Islands, p. 21.

6o The earliest history of the mission, based on Jesuit accounts, is Le Gobien, Histoire des isles Marianes. See p. 83 for Chamorri following Kepuha's example. The naming of the Church 


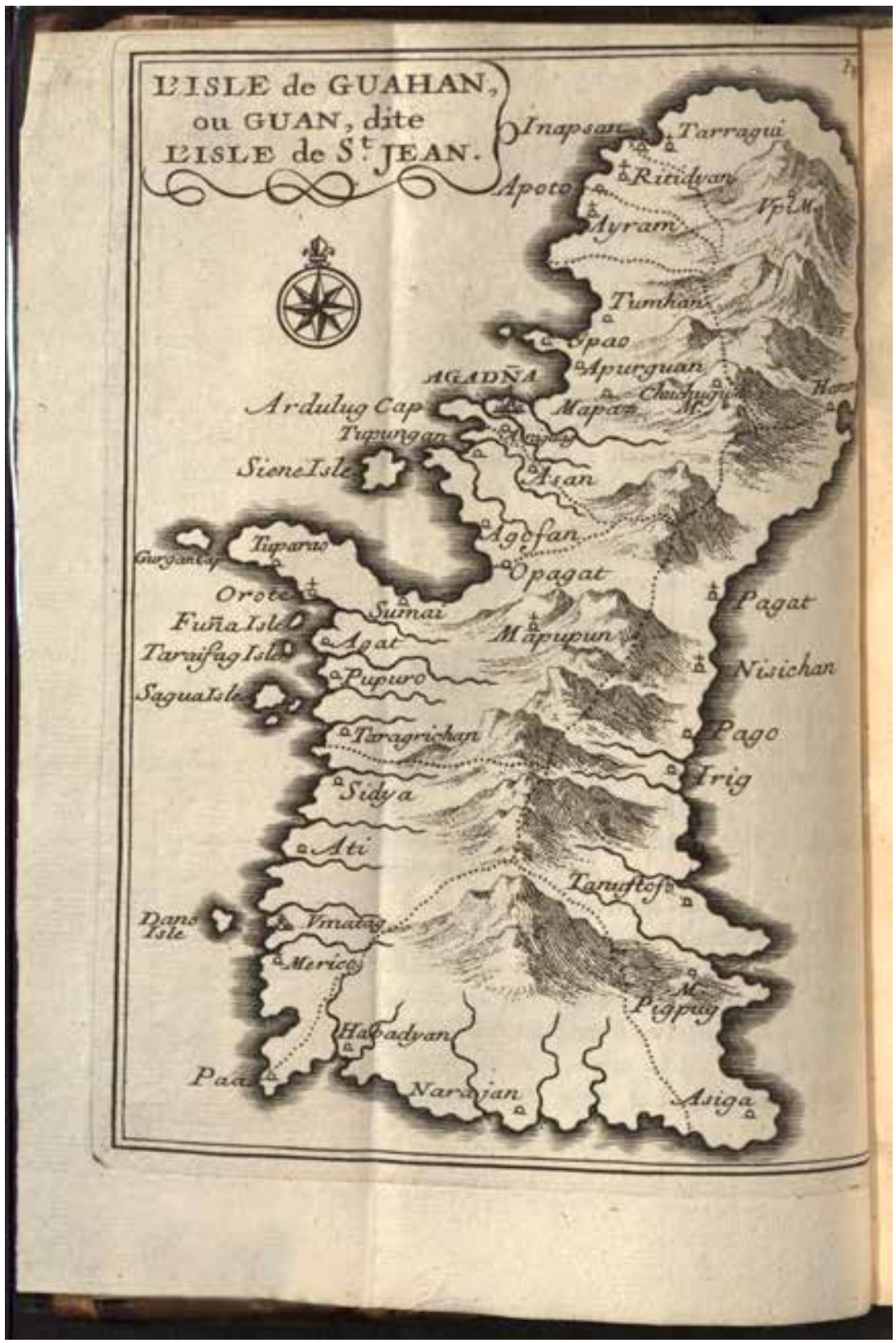

Figure 11 Map of Guam, including Jesuit headquarters of Agaña. Source: Charles Le Gobien, Histoire des isles Marianes, nouvellement converties à la religion Chrestienne; \& de la mort glorieuse des premiers missionnaires qui y ont prêché la foy (Paris: Nicolas Pepie, 1700). Courtesy of Special Collections \& Archives, UC San Diego Library. 
European missionaries and indigenous converts often hold differing views of the meaning of conversion. What may have motivated the early converts in the archipelago? One can only speculate about their motives given the lopsided nature of the historical record, all produced by the Jesuits. Still, there is clear indication that political dynamics were at play. Kepuha claimed the title 'big chief' on the island but he had at least one rival from the surrounding mountains who objected to Kepuha's inviting the Jesuits to the island. ${ }^{61}$ It appears that his support of their mission was an assertion of power if not a bid for more. To the Jesuits' consternation, Kepuha interpreted being Catholic as a clan and class privilege. He pressured them to restrict baptism to the social elite, the original Chamorri, and he tried to detain Sanvitores in his private residence and the Jesuits as a whole in Agaña, suggesting that he viewed them as a potent spiritual resource especially for himself. ${ }^{62}$ For the ruling elite - and chiefs, in particular - the ability to amass supernatural power was fundamental to gaining and maintaining political authority. ${ }^{6}$

When Kepuha died a mere six months later, it became apparent that his family's embrace of Catholicism was no less selective. The Jesuits wanted the chief, their first high-profile indigenous convert, to be buried inside their church in keeping with the European custom of honoring powerful patrons. Kepuha's clan professed loyalty to Catholicism, but insisted that their chief's remains belonged among his people and should be buried with his ancestors. ${ }^{64}$ The Jesuits won out, and they reported an apparition by Kepuha, a few days after his death, in which he revealed to one of his sons 'his luck of being in heaven. ${ }^{65}$

Like a wish of the sort that Freud saw behind dreams, the moral behind the Jesuit tale of Kepuha's appearance and appeasement of his sons was that it was easy to put to rest precontact traditions of treating ancestral remains. Historical reality ran counter to such hopes. In island culture, the dead were said to live on as spirits, and families were obligated to honor them through

is reported in Coello de la Rosa, Jesuits at the Margins, p. 32. Coello also produced an English translation and edition of Le Gobien's Histoire des isles Marianes. This English edition is based on a manuscript by Father Luis de Morales whom Coello considers the true author of the history. See Luis de Morales \& Charles Le Gobien. History of the Mariana Islands. I was unable to obtain a copy of this edition as I learned about it during the pandemic lockdown measures of 2020 while finishing the book.

61 Viana, Far Islands, p. 21.

62 Rogers, Destiny's Landfall, pp. 46-49.

63 Coello de la Rosa, Jesuits at the Margins, p. 35.

64 Rogers, Destiny's Landfall, p. 50.

65 Burial conflict and vision are reported in Le Gobien, Histoire des isles Marianes, pp. 84-85. 
ritual actions. Proper treatment of ancestral spirits promised good luck in fishing, farming, daily life, health, and war. ${ }^{66}$ Inversely, an ancestral spirit offended by neglect or the breach of a cultural taboo could wreak havoc, such as illnesses, typhoons, or crop failure. When an ancestor had died, the skull was removed from the corpse, which was buried near or under the house, and brought inside the home for veneration. Islanders presented the skulls with devotional offerings, sang songs of praise to them, and called upon the ancestral spirits in situations of need. ${ }^{67}$

The makahnas were a special group of people who mediated the relationship between ordinary islanders and the all-powerful ancestral spirits. Islanders believed they had privileged access to the spirit world and the ability to manipulate it. Clients enlisted them to translate spirit communications or determine how to mollify offended ancestors. ${ }^{68}$ They called upon makahnas to cure illnesses, produce rain and a good harvest, and luck in work and love, but also to divine the future or inflict harm, illness, or death upon a client's enemies. ${ }^{69}$ In other words, the makahnas performed services that in European parlance amounted to magic. The sources suggest that they were male spiritual leaders who also wielded considerable political influence, since living chiefs consulted ancestral spirits on matter of politics and relied upon their spiritual advice..$^{70}$ In addition, some sources report, the makahnas were in charge of special houses and caves in which the skulls of particularly important ancestors, such as clan chiefs, were preserved and presumably also consulted. ${ }^{71}$

The Jesuits initially considered the makahnas a relatively small obstacle to evangelization, mere charlatans amid a people who lacked in religion

66 Cunningham, Ancient Chamorro Society, pp. 99-100.

67 Ibid., pp. 102-104.

68 Ibid., pp. 100-102. Le Gobien accused the makahnas of conning islanders into ancestor worship for their own benefit. Le Gobien, Histoire des isles Marianes, p. 82.

69 Cunningham, Ancient Chamorro Society, p. 101.

70 On clan heads consulting spirits, see Cunningham, Ancient Chamorro Society, p. 102. The Franciscan Fray Juan Pobre de Zamora, who spent seven months stranded among the islanders in 1601, identified the makahnas as male: 'There are among them some indios that are called macana, which means a man who can heal, who can make it rain, and who knows what the future holds.' Driver, 'Fray Juan Pobre de Zamora,' p. 214. Jesuit sources for the Marianas frequently and negatively comment on the influence of women in island society, yet they do not mention any women shamans, raising the question whether there were no women among the makahnas, or whether the missionaries took only men seriously in this role. The silence about women shamans in the sources from the Marianas is the more surprising because Jesuit sources from the Philippines speak at length about female religious experts/shamans referred to as baylan as the primary opponents to successful Christianization. The women shamans in the Philippines were the target of vicious campaigns of repression. See Brewer, Shamanism.

71 Le Gobien, Histoire des isles Marianes, p. 84; Viana, Far Islands, p. 23. 
and were therefore more easily converted than avowed heretics. An early report from Guam noted that

apart from some tricksters called Macanas, who generally promise health, water, fish, and such good things by means of the invocation of the dead [...], whose skulls the Marianos keep in their houses, with no other altar, niche, or adornment than some little baskets in which they put the skulls around the house, without remembering them until it is time for the Macanas to ask the skulls for what they need. The Macanas $[\ldots .$.$] in praying to the dead, seek their own advantage through what the$ living give them and not the advantage of the living. [...] [There are] no temples, or sacrifices, or idols, or profession of any cult whatever - a fact that aids very much in introducing the Faith, if there are ministers to preach it, because it is easier to introduce a religion where there is none than to overthrow one to introduce another. ${ }^{72}$

For islanders like Kepuha, on the other hand, it was easy to see a resemblance between makahnas and the newly arrived missionaries. ${ }^{73}$ Shortly after the Jesuits' arrival, other villages requested to be sent one of the 'new makahnas. ${ }^{74}$ To be sure, Jesuits, like makahnas, were all-male spiritual elites, and both advised warriors and their chief on religion and politics. Like the makahnas, Jesuits presented themselves as healers of both body and soul, used ritual paraphernalia to communicate with the spirit world, and organized collective ceremonies of veneration. ${ }^{75}$ Both groups offered spiritual explanation for weather events, casting storms as the workings of an angry god or ancestors, or attributing the calming of the seas to the benevolence of saints or mollified spirits.

Diego de Sanvitores played on these very similarities. When drought struck Guam in June 1671, he prayed for rain in a public ceremony, usurping a traditional task of the shaman-sorcerers, and took credit when the rain came. According to Jesuit sources, the rain 'miracle' drew the ire of the makahnas, 'who saw their credibility and authority tumble' and resolved to

72 A report on the first two years of the mission published in Madrid in 1671 contains this. Barrett, Mission in the Marianas, p. 26.

73 Rogers, Destiny's Landfall, p. 48. Coello de la Rosa (Jesuits at the Margins, p. 35) reports that a chief's prestige hinged on his ability 'to accumulate supernatural power.'

74 Rogers, Destiny's Landfall, p. 48.

75 Coello de la Rosa, though he does not read the situation through the lens of gender, also remarks on the parallels and speculates that the makahnas saw the Jesuits as evil witches and spiritual rivals. Coello de la Rosa, 'Colonialismo y santitdad,' esp. pp. 726 and 730. 
expel the intruders. They spread word that angry ancestral spirits demanded such drastic action, threatening drought and famine upon the islands. More fateful still, they turned to one of the most powerful Chamorri on Guam, Chief Hurao, for military support..$^{6}$ Thus, although the equation with the makahnas helped the Jesuits in making converts, it also set them up for a competition. As it turned out, the two groups resembled one another in one final, fateful respect: jealously guarding their monopoly over the supernatural realm, they proved themselves ready to deploy the worldly weapons of war on their spiritual foes.

\section{'Shaman Battles': Physical Warfare and Spiritual Combat}

Father Luis Medina (1637-1670) was the first Jesuit to die in the Marianas. He had been among Sanvitores's original band of brothers; in fact, the two men met as young Jesuits back in Spain, years before their paths crossed again in Mexico and then aligned in this Pacific mission. ${ }^{77}$ In January 1670, islanders on Saipan speared Medina and his Filipino catechist, Hipelito de la Cruz, to death. ${ }^{78}$ By 1672 , more than half of the initial group of missionaries was dead, along with many lay helpers, Spanish soldiers, and many more islanders. Initially loath to rely upon the 30 soldiers whom the Spanish crown dispatched for their protection shortly after the fathers' landing in Guam, the Jesuits came to value the threat of violence the soldiers represented. In the wake of Medina's death, Sanvitores asked the Spanish crown for more troops to support the mission enterprise. The crown's compliance had dire long-term consequences for the local population. ${ }^{79}$

Historians have termed the decades of violent conflict the 'Spanish-Chamorro Wars,' but neither the 'Spanish' side nor the 'Chamorro' represented

76 Le Gobien, Histoire des isles Marianes, pp. 136-137. On Hurao as a mouthpiece for European ideas and debates in Gobien's narrative and on the presence of indigenous voices in Jesuit historiography more broadly, it is worth revisiting Ginzburg, 'Alien Voices.'

77 García, Life and Martyrdom, p. 13. Sanvitores first met Medina on his way to Cadiz in the city of Cordoba. They became more fully acquainted in Mexico during Sanvitores's visit from the Philippines.

78 Viana, Far Islands, p. 25.

79 Coello de la Rosa, Jesuits at the Margins, p. 39. In their report on the first two years of the mission, Jesuits highlighted the usefulness for evangelization of fear 'not only paternal but also coercive and military' and requested an additional 200 soldiers from the Queen. Barrett, Mission in the Marianas, p. 35 (quote) and p. 39 (see n. 20). Sanvitores had assembled a first squad of lay helpers, including several twelve-year-old Pampanga, in 1669 after a war between the Marpo and Sungahron clans broke out in Tinian. Atienza, 'CHamoru “Adaptive Resistance,"' p. 11. 
the kind of unified collective posited by later nationalist historiography. ${ }^{80}$ Filipinos, for example, fought on both sides. ${ }^{81}$ Islanders like Kepuha sided with the Spanish against other islanders. And only the crucible of conquest and conversion produced a unified subject population called Chamorro. Yet the violence of the clash certainly merited the term 'wars.' The Spanish military government subjected the islanders to brutal warfare and expeditions, and forcefully resettled inhabitants from the Northern Islands to Guam; the latter at the behest of the Jesuits who wished to preach to all of them at once under military protection. ${ }^{82}$ Such dramatic measures, epidemic disease, and indigenous demoralization and suicide, eventually secured Spanish dominance while the Chamorro population dropped to the brink of extinction around $1700 .{ }^{83}$

While these indigenous deaths would not be publicly commemorated until a much later date, the deaths of the Jesuits quickly reached Europe. There stories like Medina's began to cast the Marianas as a place of martyrdom. They inspired more Jesuits to join in the effort to both advance the faith in the distant archipelago and possibly die a heroic death. Medina's story appeared together with an image of the dead Jesuit (fig. 12) in a 1673 vita published by Francisco de Florencia, the Seville-based procurator for the Indies missions. ${ }^{8}$ The caption claims that Medina 'was pierced with a lance in the Marianas for the faith'; that is to say, he had died a true martyr's death in defense of Christianity. The lance that protrudes from Medina's chest to aim directly at the heart of the crucified Christ in his arms reiterates the point.

The piercing lance notwithstanding, the Jesuit exudes composure and calmness in this portrait. The ardor for martyrdom, described in Jesuit letters as a burning desire to cross seas and die most violently amid infidels at the ends of the earth, has resolved itself into dreamy contentedness in the image of a dead man. If Jesuit writings on the subject are often effusive to set men in motion, images like this one appear to make visual arguments for goal-directed containment. The Jesuit image of male martyrdom by

80 Hezel, When Cultures Clash.

81 Filipino soldiers were brought by the Spanish but then also staged a series of mutinies during key moments. Viana, Far Islands; Mawson, 'Rebellion and Mutiny.'

82 Hezel, From Conquest to Colonization, pp. 1-14.

83 Scholars make varying estimates of the overall numbers of the Chamorro population as well as the causes behind the dramatic death rates. See Shell, 'The Marianas Population Decline.' David Atienza stresses low natality rate as a key factor in the rapid decline. Atienza, personal communication, February 2020.

84 De Florencia, Exemplar. 


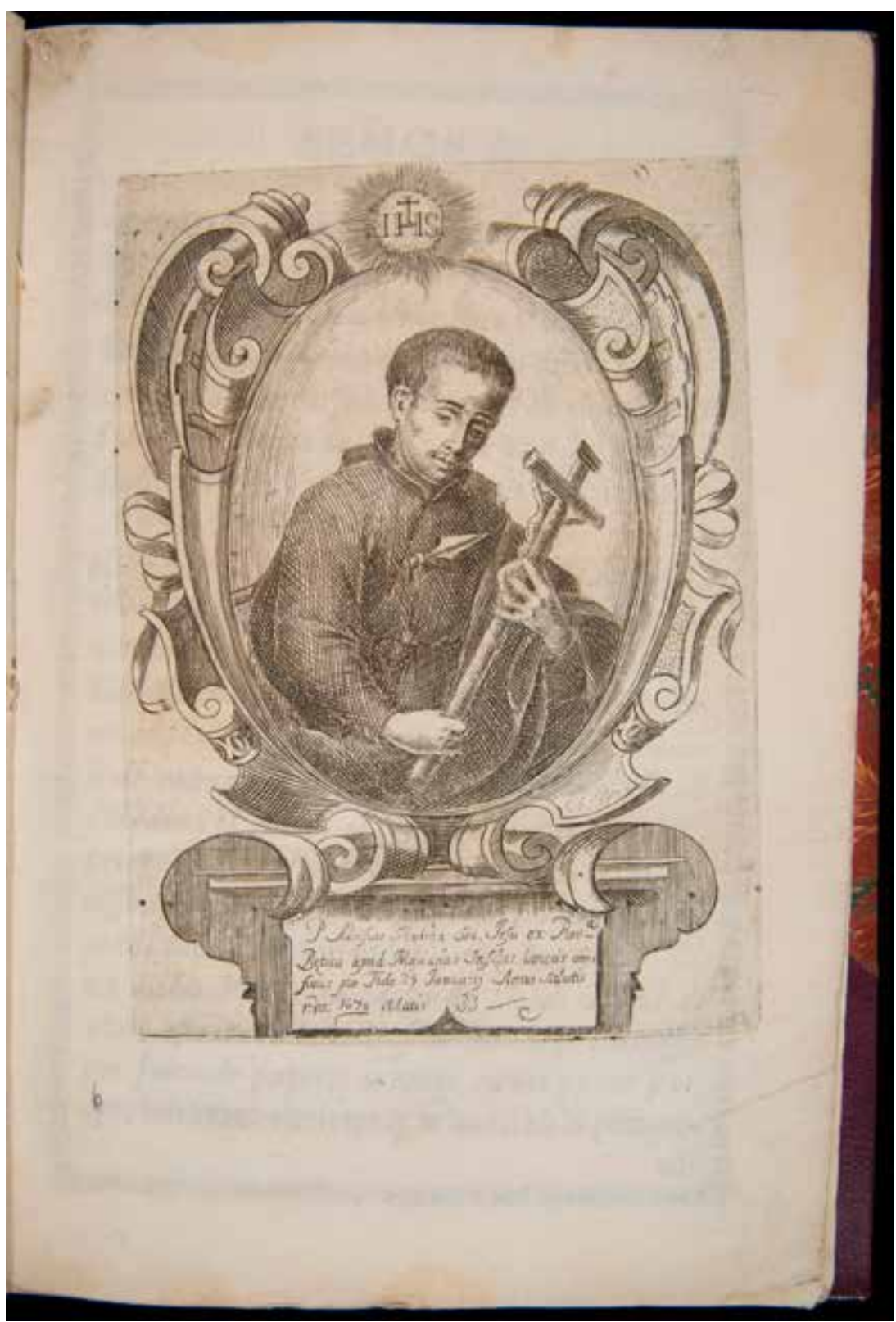

Figure 12. Francisco de Florencia, Exemplar vida y gloriosa muerte por Christo del fervoroso P. Luis Medina [...] sacada de las noticias que el Padre Diego Luis de Sanvitores, Superior de las Missiones Marianas, dio al R. Padre Provincial de las Filipinas (Sevilla: Iuan Francisco de Blas, 1673). Copyright The Newberry Library, Chicago. 
penetration of the chest by Chamorro lance has an intriguing counterpoint in a roughly contemporary visualization of an emblematic female mystical death. Just a few decades earlier, Gian Lorenzo Bernini gave form to Teresa of Avila's ecstatic experience of mystical death, capturing it at the moment prior to her penetration by a spear into her chest. Teresa and other charismatic women understood the mystical death as an imaginary form of martyrdom. ${ }^{85} \mathrm{~A}$ reliving of Christ's passion rather than a literal shedding of blood it was achievable within the confines of Tridentine enclosure. A death like Medina's, on the other hand, presupposed apostolic mobility and exposure to the unbelievers on the outer frontiers of Catholic Christianity. His ecstatic longings had to be both sufficiently strong to motivate him for the high-risk mission and sufficiently harnessed to the long-term goals of the order.

Medina's actions prior to the islanders' attack were part of the escalating spiritual battle between missionaries and makahnas. The Jesuit had been baptizing children on Saipan, an act that had become associated with black magic, and he had been burning various types of 'idols. ${ }^{86}$ Before his death, Medina requested that the islanders hand over their ancestors' skulls so that he could destroy what were sacred vessels of ancestral spirits to the indigenous but sacrilegious objects to the Jesuits. ${ }^{87}$ Medina's actions, in other words, struck to the heart of the belief systems of both intruders and indigenous and stirred up the rivalry between the missionaries and makahnas.

An ally of the makahnas named Choco, whose wife was from Saipan, played a role in the islanders' rejection of baptism. Choco had shipwrecked in the archipelago in 1648 , taken a wife, and stayed in Guam. He was Chinese, and the Jesuits speculated that he may have introduced ancestor worship in the Marianas. He could work iron, a highly valued commodity, and was rumored to have been a supporter of Buddhism. ${ }^{88} \mathrm{He}$ had been in the initial wave of converts, with Sanvitores christening him 'Ignacio,' yet he quickly turned against the Jesuits. ${ }^{89}$ Choco claimed that baptism and extreme unction were acts of black magic that killed children and elders through contact with their allegedly holy water and oil. Given the death toll that European germs took among infants and old people, this was a most potent charge. $9^{0}$

86 Coello de la Rosa, Jesuits at the Margins, p. 35.

87 Viana, Far Islands, p. 25.

88 Russell, Tiempon I Manmofo'na, p. 297; Viana, Far Islands, p. 23.

89 Rogers, Destiny's Landfall, p. 49.

90 Viana, Far Islands, p. 24. 
By baptizing children and asking for the destruction of ancestral remains, Medina had picked up the hottest political potatoes on the islands. His violent death was a symbol of irreconcilable differences, as was the fate of his own material remains. A few months after the killing, a Spanish search party traveled to the hostile islands to recover Medina's body. ${ }^{11} \mathrm{Just}$ like the islanders treasured the remains of ancestors, European Christians expressed their veneration of exceptional people who had gone before them by preserving their bones as relics, often skulls. They too preserved them in special houses called churches. The party found Medina's corpse in April 1671, only to discover that some of his bones had been put to a different purpose. In the absence of metal ores, islanders customarily carved the arm and leg bones of dead enemies into spear tips and lances of the kind that killed Medina in the first place. They attached cords to the arms and legs before burying corpses upside down so they could easily retrieve the bones once the flesh had decomposed..$^{92}$ By the time the Europeans arrived at Medina's burial site, his strings had been pulled already. The upper-body portrait Francisco de Florencia published in 1673 was thus a posthumous restoration to wholeness. The spear tip of human bone indexes not only Medina's fate as a martyr but, more disturbingly, raw material for a Chamorro weapon. The European search party collected what was left of Medina and buried the bones below the main altar in the church in Agaña, gathering up the spiritual potency associated with every fragment of a martyr's body and depositing it at the spiritual center of their mission. 93

As it happened, the mission in Agaña became the site of the showdown of the so-called first Great War of Guam in fall 1671 . Conflict between islanders and intruders had been heating up over the summer. The killing of a Mexican catechist in July 1671 proved to be the spark for a full-scale military clash. Named José de Peralta, the man was killed in the symbolic act of cutting wood to make crosses, prominent signs of the Jesuit takeover, by allies of Chief Hurao, chosen leader of the makahnas. ${ }^{94}$ The Spanish rounded up suspects in retaliation, killing one of them, a high-ranking member of the original Chamorro class, angering his clan and fanning the flames of the rebellion. During the summer months, Hurao united the disgruntled islanders

91 Coello de la Rosa, Jesuits at the Margins, p. 38.

92 Viana, Far Islands, endnote 55 on p. 51.

93 His catechist's remains, too, were recovered and buried there as well. Rogers, Destiny's Landfall, p. 51. Medina's relics attracted devotion by the public. Coello de la Rosa, Jesuits at the Margins, p. 40.

94 Viana, Far Islands, p. 28. 
behind him to launch a full-scale attack on Agaña in September 1671. Choco and the makahnas joined them. ${ }^{95}$

Spiritual and military combat now went hand in hand. September brought drought to the islands. The makahnas, urging on the troops, explained it as the demand of ancestral spirits, angered by their people's abandonment, to expel the outsiders from the island. When a typhoon struck in October and destroyed not only the homes of the insurrection leaders, but also the Jesuit church and mission residence, the weather event was ripe for competing interpretations by both parties..$^{6}$ Although Jesuits regularly and successfully interpreted weather events on ships during the journey and were thus prepared to play this role on the ground, their spiritual interpretations did not go uncontested in a mission site like the Marianas.

Hostilities and shaman battles reached their peak when the makahnas, to cheer on and support the rebel troops, hauled several hundred ancestral skulls to the front line and surrounded the fortress-complex with the physical manifestation of the ancestral spirits. ${ }^{97}$ Bones were a means of communication not only with the world of the spirits, but also with one's enemies. This held true in both directions. At the end of the day, the Spanish-led forces broke free and dealt a crushing defeat to their attackers. The Europeans may have considered the skulls idols, yet what followed the lifting of the siege shows that they implicitly had to recognize the bones' potency in island culture: They publicly smashed every single one of the hundreds of skulls to disprove their power..$^{8}$ The iconoclastic spectacle recalls the shaman battles that took place in the Jesuit Paraguay mission, where Antonio Ruiz de Montoya faced off with Guarani shamans, including contestation over the significance of alleged 'holy bones. ${ }^{99}$ As regards the Marianas, according to Jesuit sources, the defeat of the Chamorro rebels in October 1671 taught the islanders that 'their Macanas were imposters and their Anitis could not stop the bullets of the muskets,' cementing their faith in the Christian god and the Jesuits. ${ }^{100}$ However, this was wishful thinking. Sanvitores suspected that much, and in the war's wake he asked for more soldiers and a better fortress. ${ }^{101}$

96 Viana, Far Islands, pp. 28-29.

97 Rogers, Destiny's Landfall, p. $5^{2}$.

98 Viana, Far Islands, p. 28.

99 Tuer, 'Old Bones.'

100 Le Gobien, Histoire des isles Marianes, pp. 152-153, esp. p. 149.

101 Coello de la Rosa, Jesuits at the Margins, p. 41. 
Sanvitores never saw the fulfillment of these material requests, but his deepest spiritual desire was met in April 1672. A Chamorro chief named Matå'pang speared the Jesuit to death with a lance made of human bone because Sanvitores had baptized the chief's infant daughter over his objections. Matå’pang, like Kepuha and others before him, had actually embraced Christianity and Sanvitores before he set out to annihilate both. The chief had let himself be baptized by Sanvitores, and later on, he called upon the Jesuit to heal him when another islander had wounded Matå'pang with a lance. ${ }^{102}$ These early interactions are suggestive of a relationship of spiritual trust and of viewing the Jesuit as an ally of sorts.

It is worth noting, though, that the Jesuits sought out primarily male chiefs as allies and only rarely relied upon the cooperation of female leaders. ${ }^{103}$ They were men shaped by European patriarchy for whom other men, not women, were their natural political and religious allies. In the extant and exclusively European sources, the importance of women in matrilineal island society registers in the interstices. Jesuits recorded that the Chinese immigrant and political instigator Choco found his way into Chamorro society by taking a local wife, or that Chief Matå'pang killed Sanvitores over baptizing his female offspring. They also commented on matrilineality and not favorably, as we will see. Yet island society, too, in spite of the matrilineal nature of clans and resource control, apparently had its own patriarchal slant and tendencies. Political power or governance seems to have rested primarily in the hands of men. Earlier Jesuit sources further indicate that patriarchy had its appeal to indigenous men. Noting the kind of submissive women who frequented the Jesuit church on Sundays, they gave Christian marriage serious consideration: 'Seeing those women so diligent and so circumspect, the natives wished their own wives might be like them, and when they heard that this was a grace conferred by holy matrimony, they began to take a favorable view of the sacrament.' ${ }^{104}$ Female submission appears the big selling point for Christian marriage for some male islanders. The following chapter will consider the implications of conquest and conversion for women more fully.

Although European Jesuits came to the Marianas to make Catholics of the islanders, Christianization only took hold in the Pacific archipelago because

102 García, Life and Martyrdom, p. 251.

103 In the district of Sydya, 'a woman who governed' and converted to Christianity persuaded her community to turn over the murderer of Fr. Ezquerra and other offenders in return for peace with the Europeans. García, Life and Martyrdom, p. 492.

104 García, Life and Martyrdom, pp. 485-486. 
some islanders made makahnas out of Jesuits, interpreting the missionaries and their message within a cultural framework built around ancestor worship and shaman-sorcerers. Important converts like Chief Kepuha were looking for new and better makahnas in the Jesuits, who could help them address traditional needs and increase their social and political influence. Jesuits like Sanvitores in turn played on the resemblance to the indigenous alter egos, reinforcing the comparison in the belief that the makahnas were 'tricksters' and minor obstacles on the path to Christianization.

The shamans, however, proved to be formidable adversaries who aligned themselves with powerful chiefs to oppose the European intruders. Men aligned themselves on the front lines of both side of the divide between the Europeans and the islanders. Whether intentional or not, the prominent role of male shamans in sparring with the Jesuits amounted to a bid for greater spiritual power in the archipelago. Matrilineal island culture associated women with the very foundation of the earth, the continued fertility of the world and its people. This cosmic female principle and the women who embodied it came to recede in importance during the high-stakes spiritual battles between makahnas and missionaries. For a while, the makahnas seemed to be winning. By April 1672, Matåpang had apparently come to associate Sanvitores with trickery and reaffirmed his previous connection to the spirit world of the ancestors ruled by the makahnas and represented by skulls in family homes. The challenge Matå'pang issued to Sanvitores when the Jesuit approached the Chamorro's house to baptize his daughter indicates this: 'Go ahead, imposter, go into my house and baptize a skull there. ${ }^{105}$ Matå'pang no longer had faith in Sanvitores and Christianity, but rather placed stock in the abiding power of ancestral skulls.

In the contestation for supremacy that ensued, Jesuits abandoned their critical stance toward military force and came to rely upon the dirty business of colonial warfare to dislodge their rivals and assert spiritual hegemony in the islands. The difference between being a persuasive missionary and being a violent conquistador increasingly collapsed in the Marianas. After his killing, Sanvitores was immediately hailed as a martyr. Brethren in the Marianas, Philippines, and Mexico spread the news of Sanvitores's alleged glorious death for the faith. ${ }^{106}$ Fittingly, the news arrived in among those who had stayed behind in his college in Spain on the feast day of Ignatius. It also spread to other parts of Europe and made its mark on the hearts and minds of the next generation of Jesuits. Just like Xavier's example had pulled Sanvitores

105 Ibid., p. 251.

106 Rogers, Destiny's Landfall, p. 56. 
toward the Pacific mission and a bloody death, Sanvitores's example inspired more Jesuits in Europe to join the Marianas mission and seek martyrdom. Thus, the story of yet another Iberian Jesuit sparked the desires of men in German lands, directing their movements toward distant shores.

\section{Bibliography}

\section{Primary Sources}

Barrett, Ward J., ed. Mission in the Marianas: An Account of Father Diego Luis de Sanvitores and His Companions, 1669-1670 (Minneapolis: James Ford Bell Library at the University of Minnesota, 1975).

Colin, Francisco. Labor evangelica, ministerios apostolicos de los obreros de la Compañia de Iesvs, fvndacion, y progressos de sv provincia en las islas Filipinas (Madrid: Joseph Fernandez de Buendia, 1663).

De Florencia, Francisco. Exemplar vida y gloriosa muerte por Christo del fervoroso P. Luis Medina [...] sacada de las noticias que el Padre Diego Luis de Sanvitores, Superior de las Missiones Marianas, dio al R. Padre Provincial de las Filipinas (Sevilla: Iuan Francisco de Blas, 1673).

Driver, Marjorie G. 'Fray Juan Pobre de Zamora and His Account of the Mariana Islands.' Journal of Pacific History 18, no. 3 (1983), pp. 198-216.

García, Francisco. The Life and Martyrdom of the Venerable Father Diego Luis de San Vitores of the Society ofJesus, First Apostle of the Mariana Islands and Events of These Islands from the Year Sixteen Hundred and Sixty-Eight through the Year Sixteen Hundred And Eighty-One. Trans. Margaret M. Higgins, Felicia Plaza, and Juan M.H. Ledesma. MARC Monograph Series no. 3 (Mangilao: Micronesian Area Research Center, University of Guam, 2004.)

García, Francisco. Vida y martyrio de el Venerable Padre Diego Luis de Sanvitores de la Compañia de Jesus, primer apostol de las islas Marianas, y sucessos de estas islas, desde el año de mil seiscientos y sesenta y ocho, hasta el de mil seiscientos y ochenta y uno (Madrid: J. García Infanzón, 1683).

Le Gobien, Charles. Histoire des isles Marianes, nouvellement converties à la religion Chrestienne; \& de la mort glorieuse des premiers missionnaires quiy ont prêché la foy (Paris: Nicolas Pepie, 1700).

Lévesque, Rodrigue, ed. History of Micronesia: A Collection of Source Documents, Vol. 4: Religious Conquest, 1638-167o (Gatineau: Lévesque Publications, 1995). Morales, Luis de \& Charles Le Gobien. History of the Mariana Islands (Mangilao: Micronesian Area Research Center, University of Guam Press, 2016). Trans. and ed. by Alexandre Coello de la Rosa. 


\section{Secondary Sources}

Alkire, William. An Introduction to the Peoples and Cultures of Micronesia (Menlo Park, CA: Cummings Pub. Co., 1977).

Atienza, David. 'CHamoru “Adaptive Resistance” during the Spanish Conquest and Colonization of the Marianas Islands,' paper presented at the Fourth Marianas History Conference, University of Guam, August 31-September 1, 2019.

Atienza, David. 'Priests, Mayors and Indigenous Offices: Indigenous Agency and Adaptive Resistant in the Mariana Islands (1681-1758).' Pacific Asia Inquiry 5, no. 1 (2014), pp. 31-48.

Atienza, David, and Alexandre Coello de la Rosa. 'Embodied Silent Narratives of Masculinities: Some Perspectives from Guam Chamorros,' in Narrative and Identity Construction in the Pacific Islands, ed. Farzana Gounder (Amsterdam: John Benjamins, 2015), pp. 243-258.

Brewer, Carolyn. Shamanism, Catholicism and Gender Relations in Colonial Philippines, 1521-1685 (Aldershot: Ashgate, 2004).

Brown, Kathleen M. 'Gender Frontiers and Early Encounters,' in The Oxford Handbook of American Women's and Gender History, ed. Ellen Hartigan-O'Connor and Lisa G. Matterson (Oxford: Oxford University Press, 2018), pp. 19-41.

Burschel, Peter. 'Einleitung,' in Vorbild, Inbild, Abbild: Religiöse Lebensmodelle in geschlechtergeschichtlicher Perspektive, ed. Peter Burschel and Anne Conrad (Freiburg im Breisgau: Rombach, 2003), pp. 9-21.

Burschel, Peter. 'Männliche Tode - weibliche Tode. Zur Anthropologie des Martyriums in der frühen Neuzeit.' Saeculum 50, no. 1 (1999), pp. 75-97.

Burschel, Peter. Sterben und Unsterblichkeit: Zur Kultur des Martyriums in der frühen Neuzeit (München: Oldenbourg Verlag, 2004).

Coello de la Rosa, Alexandre. 'Colonialismo y santitdad en las islas Marianas: La sangre de los mártyres (1668-1676).' Hispania Sacra 128 (2011), pp. 707-745.

Coello de la Rosa, Alexandre. Jesuits at the Margins: Missions and Missionaries in the Marianas (1668-1769) (London: Routledge, 2016).

Cunningham, Lawrence J. Ancient Chamorro Society (Honolulu: Bess Press, 1992).

D'Arcy, Paul. The People of the Sea: Environment, Identity, and History in Oceania (Honolulu: University of Hawai'i Press, 2006).

Davidson, Arnold I. 'Miracles of Bodily Transformation, or How St. Francis Received the Stigmata.' Critical Inquiry 35, no. 3 (2009), pp. 451-48o.

Diaz, Vincente M. Repositioning the Missionary: Rewriting the Histories of Colonialism, Native Catholicism, and Indigeneity in Guam (Honolulu: University of Hawai'i Press, 2010).

Ditchfield, Simon. 'Decentering the Catholic Reformation. Papacy and Peoples in the Early Modern World.' Archiv für Reformationsgeschichte 101 (2010), pp. 186-208. 
Ginzburg, Carlo. 'Alien Voices. The Dialogic Element in Early Modern Jesuit Historiography,' in idem History, Rethoric, Proof (Hanover, NY: University Press of New England, 1999), pp. 71-91.

Hezel, Francis X. From Conquest to Colonization: Spain in the Mariana Islands, 1690 to 1740 (Saipan: Division of Historic Preservation, 1989).

Hezel, Francis X. 'From Conversion to Conquest: The Early Spanish Mission in the Marianas.' Journal of Pacific History 17, no. 3 (1982), pp. $115^{-137 .}$

Hezel, Francis X. When Cultures Clash: Revisiting the Spanish Chamorro Wars (Saipan: Northern Marianas Humanities Council, 2015).

Hsia, Ronnie Po-chia, ed. Noble Patronage and Jesuit Missions: Maria Theresia von Fugger-Wellenburg (1690-1762) and the Jesuit Missionaries in China and Vietnam (Rome: Institutum Historicum Societatis Jesu, 2006).

Hufton, Olwen. 'Altruism and Reciprocity: The Early Jesuits and Their Female Patrons.' Renaissance Studies 15, no. 3 (2001), pp. 328-353.

Leone, Massimo. Saints and Signs: A Semiotic Reading of Conversion in Early Modern Catholicism. (Berlin: De Gruyter, 2010).

Levy, Evonne. 'Jesuit Identity, Identifiable Jesuit? Jesuit Dress in Theory and Image,' in Le monde est une peinture: Jesuitische Identität und die Rolle der Bilder, ed. Elisabeth Oy-Marra and Volker R. Remmert (Berlin: Akademie-Verlag, 2011), pp. 127-152.

Matsuda, Matt K. Pacific Worlds: A History of Seas, Peoples, and Cultures (Cambridge: Cambridge University Press, 2012).

Mawson, Stephanie. 'Rebellion and Mutiny in the Mariana Islands, 1680-169o.' Journal of Pacific History 50, no. 2 (2015), pp. 128-148.

Newman, William R. Promethean Ambitions: Alchemy and the Quest to Perfect Nature (Chicago: University of Chicago Press, 2004).

Rogers, Robert F. Destiny's Landfall: A History of Guam (Honolulu: University of Hawai'i Press, 1995).

Rublack, Ulinka. Dressing Up: Cultural Identity in Renaissance Europe (Oxford: Oxford University Press, 2010).

Russell, Scott. Tiempon I Manmofo'na: Ancient Chamorro Culture and History of the Northern Mariana Islands (Saipan: Division of Historic Preservation, 1998).

San Juan, Rose Marie. Vertiginous Mirrors: The Animation of the Visual Image and Early Modern Travel (Manchester: Manchester University Press, 2011).

Shell, Richard J. 'The Marianas Population Decline: 17 th-Century Estimates.' Journal of Pacific History 34, no. 3 (1999), pp. 291-305.

Tuer, Dot. 'Old Bones and Beautiful Words: The Spiritual Contestation between Shaman and Jesuit in the Guaraní Missions,' in Colonial Saints: Discovering the Holy in the Americas 1500-180o, ed. Allen Greer and Jodi Bilinkoff (New York: Routledge, 2003), pp. 77-98. 
Viana, Augusto V. de, In the Far Islands: The Role of Natives from the Philippines in the Conquest,Ccolonization and Repopulation of the Mariana Islands 1668 1903 (Manila: University of Santo Tomas Publishing Houses, 2004)

Županov, Ines G. 'The Art of Dying in the Tropics,' in idem, Missionary Tropics: The Catholic Frontier in India (16th-17th Centuries) (Ann Arbor: University of Michigan Press, 2005), pp. 147-171.

Županov, Ines G. 'Passage to India: Jesuit Spiritual Economy between Martyrdom and Profit in the Seventeenth Century.' Journal of Early Modern History 16 (2012), pp. 121-159. 